\title{
Fejezetek a függvénytanítás történetéből - Beke Manó és Varga Tamás koncepciói
}

A magyar matematikatanitás történetének kiemelkedó állomása Varga Tamás komplex matematikatanitási kísérlete, amelynek eredményei mindmáig meghatározóak a magyar matematikatanításban. Függvényközpontú matematikaoktatási szemléletének, a függvényekkel kapcsolatos tanitási elképzelésének. fóbb gondolatait foglalja össze a tanulmány, megidézve ehhez Beke

Manó tevékenységét is a függvénytanitás terén.

\section{Matematikatanítás - függvénytanítás a 19. század fordulóján}

A 19. század végéig a függvények tanítása alig jelent meg az oktatásban. A gyökeres változást ebben az iskolai tantervek reformja hozott a 20. század elején, melyben fontos szerepe volt a Felix Klein által kezdeményezett Meráni Reformnak (1905) (Schubring, 2014. 248.). A függvények, a függvényszerü gondolkodás tanításának központi szerepet szánt Felix Klein, amikor hangsúlyozta, hogy az általános függvényfogalomnak a felsőbb iskolák egész matematikaoktatását át kell hatnia, és nem csupán absztrakt definíciókkal kell bevezetni a fogalmat, hanem a hallgatók számára „élővé” is kell tenni elemi példák segítségével, ahogy ez, mint írja, már Eulernél is megtalálható (Klein, 1932. 205.).

Felix Klein (1849-1925) matematikusként kiemelkedő sikereket ért el a geometria területén és többek között a matematika alkalmazásaival is foglalkozott. A matematika egyetemi és középiskolai tanításának megreformálásában úttörö szerepet játszott, ő volt az első vezetője az 1908-ban alapított, azóta is tevékenykedő nemzetközi matematikaoktatással foglalkozó szervezetnek az ICMI-nek (International Commission on Mathematical Instruction). Felix Klein tevékenysége elsősorban Beke Manó révén hatott a magyar matematikaoktatásra.

Beke Manó (1862-1946) matematika-fizika szakos tanárként végzett, egy ideig gimnáziumi tanárként is müködött. 1900-ban egyetemi tanár, 1914-ben a Magyar Tudományos Akadémia levelező tagja lett. Az egyetemen többek között tanítványai voltak Pólya György, Szegő Gábor és Kőnig Dénes is. Már pályája kezdetétől foglalkozott tanügyi, matematikatanítási kérdésekkel. Az 1892-93-as göttingeni tanulmányútján nemcsak matematikai kutatásokat végzett Felix Kleinnél, hanem megismerkedett a matematikatanítási reform-elképzeléseivel is, és ezek nagy hatással voltak rá. Kleinnel hazatérése után is szoros kapcsolatban maradt (Kántor, 2014).

Beke kezdeményezésére jött létre a magyar Matematikai Reformbizottság, melynek elnöke lett, a titkár pedig Mikola Sándor, akivel közösen írta meg a „A középiskolai 
matematikatanítás reformja" (1909) című tanulmánykötetet. A bizottság fő törekvése volt a küzdelem a formális matematikaoktatás ellen és egy munkáltató matematikaoktatás megteremtése. „A reformtól Beke Manó azt várta, hogyha ilyen szellemben átalakítják a matematikaoktatást, akkor elérhetik a legföbbet: a középiskolai tanulókban felébresztik a matematika iránti kedvet" (Kántor, 2014. 10.).

A kiegyezés (1867) utáni Magyarországon a gyors iparosodás igényt teremtett a természettudományok intenzívebb múvelésére is, amelynek hatása az oktatásban is megmutatkozott. Egymás után megjelenő tantervek jelzik (1869, 1871, 1879, 1899), hogy jelentős változás indult meg. Beke úgy vélte, hogy ezek közül igazi változást csak a legutolsó, a Wlassics-féle tanterv hozott, 1899-ben, különösen az alkalmazások tanítása terén (Beke és Mikola, 1909. 13.).

Tudományos tevékenysége mellett jelentős Beke módszertani, illetve tankönyvszerzői munkássága is; tudományos tevékenységét háttérbe szorítva, 1890 és 1900 között 10 tankönyvet írt, amelyeket a 20. század első felében még évtizedekig használtak az iskolákban. Beke minden szinten írt tankönyveket, az elemi iskolától az egyetemig. Az elemi iskolai számtantanítás szempontjából kiemelném a tanítók számára írt Vezérkönyv a népiskolai számtani oktatáshoz (1896) című könyvét, amelyben a számtantanítás történeti ívének megrajzolásával alapozza meg tananyagfelépítési és módszertani javaslatait.

A 19. század vége felé kezdte meg korábbi tanára, a matematikus König Gyula középiskolai tankönyveinek átdolgozását a szerző hozzájárulásával. Az átdolgozás eredményeit egymás utáni kiadásokban követhetjük nyomon. Az újabb kiadások 1913-tól Kőnig kívánságára - már csak Beke Manó neve alatt jelentek meg.

Az 1892-93-as göttingeni évek után még intenzívebben kezdett foglalkozni a matematikatanítás kérdéseivel, illetve azok megreformálásával. Vezetője lett a századforduló magyarországi matematikatanítási reformmozgalmának, melynek főbb célkitüzései megegyeznek Felix Klein 1905-ös programjával.

A matematikatanítással kapcsolatos reformelképzelések között hangsúlyozottan szerepel nemcsak a számtantanítás gyakorlatibbá tétele, a térszemlélet fejlesztése, hanem a mennyiségek közötti kapcsolatok vizsgálata, grafikus reprezentációja, a függvényfogalom szisztematikus fejlesztése, a differenciál és integrálszámítás elemeinek bevezetése és használata (Beke és Mikola, 1909).

\section{Függvényfogalom és függvénytanitás}

A magyar középiskolai tankönyvekben a „függvény” elnevezés a 19. század közepén jelent meg, abban az értelemben, ahogy Euler is használta; a függvényt egyetlen algebrai kifejezés adja meg, a teljes értelmezési tartományon. A következő mintegy száz évben a középiskolás függvényekre vonatkozó tananyagban a függvények megadásához gyakorlatilag képleteket használtak, csak egyes helyeken jelent meg utalás a hozzárendeléssel történő megadásra (Katz, 1989).

A Beke által kezdeményezett és irányított matematikatanítási reformok a függvények bevezetését már alsóbb osztályokban (1-4) is javasolták elkezdeni az akkori nyolcosztályos középiskolában. A kezdeteket mennyiségi kapcsolatok feltárása, mennyiségek egymástól való függésének vizsgálata jelentette. Ebben fontos szerepet szántak valós adatok felhasználásának amelyek kísérletekből, tanulói mérésekből származtak (Goldzieher, 1909. 74.).

A magyar reformokat támogató matematikatanárok közül kiemelkedik Rátz László (1863-1930) tevékenysége - ő volt többek között Neumann János és Wigner Jenő tanára is. A híres Fasori Gimnáziumban tanított, ahol tanulói tevékenységre épített matematikatanítási módszert dolgozott ki Mikola Sándor (1871-1945) matematika-fizika szakos tanárral közösen, amely gyakorlatilag a reformok egyfajta korai iskolai megvalósulásának is tekinthető. 1902-től ebben a gimnáziumban már engedélyeztek e módszer alapján 
történő matematikatanítást. Ez az oktatási elképzelés a matematikatanítás középpontjába a függvények tanítását tette, melynek során mérések, gyakorlati kísérletek segítségével a függvényszerü gondolkodás, a függvények ábrázolása már az alsóbb középiskolai osztályokban megkezdődött (Némethné, 2006).

A függvények tanításának gazdag gyakorlati tartalma és hangsúlyozott volta nyomon követhető az átalakított tananyagban,

„...a három alsó osztályban is lehet már egyszerű grafikus ábrázolásokat végezni. A IV. osztályos anyaghoz hozzávették a függvények változásának és ábrázolásának tárgyalását. Olyan, a gyakorlati életben is használható grafikonokkal foglalkoztak, mint az idő és valamely értékpapír árfolyama; idő és hőmérséklet; csapadék és légnyomás; kor és halálozási százalék. Az V. osztályban előírt anyaghoz hozzátették a másodfokú függvény változásának leírását és a másodfokú egyenlőtlenségek megoldását. A VI. osztályos tananyagban többletként szerepelt a kamatos kamatés járadékszámítás, és az előforduló logaritmikus és trigonometrikus függvények ábrázolása. VII. osztályban helyet kaptak az elemző mértan egyszerü feladatai, a koordinátageometria elemei és a differenciálszámítás. A VIII. osztályos anyagba helyezték az integrálszámítás tárgyalását a gömbre vonatkozó számításokkal". (Mikola és Rátz, 1910 bevezetője alapján: Némethné, 2006. 35.).

A már említett Beke által átdolgozott középiskolai algebra tankönyvekben a függvények algebrai kifejezések formájában jelentek meg, melyek értéke az ismeretlen értéktől függ (vö. Beke és König, 1897, 1908).

A tankönyvekben Az algebra és geometria viszonya fejezetben található a függvények általános tárgyalása, majd a fejezet végén kerül említésre az elsőfokú függvény, mint speciális esete az n-d fokú egész függvénynek $\left(\mathrm{A}+\mathrm{Bx}+\mathrm{Cx}^{2}+\ldots+\mathrm{Nx}^{\mathrm{n}}\right)$, és Beke az elsőfokú függvényekkel illetve ábrázolásukkal kapcsolatban a következőket írja: „,...Eszerint az $\mathrm{y}=\mathrm{ax}+\mathrm{b}$ elsőfokú egész függvény. Könnyü lesz kimutatni, hogy e függvény menetét ábrázoló vonal mindig egyenes." (Beke és König, 1897. 263.; Beke és Kőnig, 1908. 314-315.). A következő fejezetben, amely a másodfokú egész függvényekről szól, a bevezető rész sze-

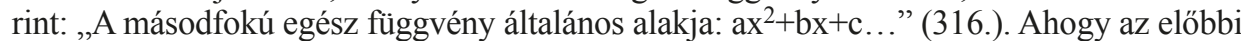
részletek is valamennyire illusztrálják, a tankönyvekben a függvények esetében a változó mennyiségek közötti kapcsolat volt a hangsúlyos, még nem volt szó például „,egyértelműség"-röl, és az y= .. felírásmódot inkább függvények ábrázolásánál használták, de azt sem következetesen, viszont igen fontos volt a függvények grafikus ábrázolása.

A függvényekröl szóló ismeretek és a függvények alkalmazásainak gazdagodását kísérhetjük nyomon a Beke tankönyv egymás utáni átdolgozott kiadásaiban. Megjelenik például a gyakorlati adatokon alapuló függvények vizsgálata, és függvények alkalmazása problémamegoldásban, növekszik a tankönyvi feladatok száma, (1. például az előbb említett fejezetben: Az algebra és geometria viszonya, Beke, 1897, 1908), és - a koordinátarendszer bevezetésével - az adatok közötti dinamikus kapcsolatok vizsgálata is elötérbe kerülelsősorban a matematika alkalmazásaiban.

Példaként említem a tankönyv 1908-as kiadásából azt a feladatot, amely a lineáris függvény (grafikonjának) egy gyakorlati alkalmazását mutatja be. Beke a következőt írja a tankönyvben is szereplö menetrend grafikonhoz (1. ábra) feladatul:

„A mellékelt 22-ik ábrában feltüntettük a szombathely-fehringi vonat grafikus menetrendjének egy szakaszát. A vastag vonal gyorsvonatot, a vékonyabb személyvonatot, az egész vékony tehervonatot, a pontozott vegyes vonatot stb. jelent. Az időt déli 12-től éjfélig vettük és minden köz 10 percet jelent.

Próbáld elolvasni erről a képről, hogy mikor indul Szombathelyről Fehringbe a délutáni gyors? Mikor érkezik a fehringi gyors? Mikor érkezik Fehringbe az estéli 
gyors? Hol talákozik az 1303-as gyors az 1808-as személlyel? Hol találkozik ez a gyorsvonat az 1394-es tehervonattal? Meddig áll Körmenden az 1394-es tehervonat? stb.“ (Beke \& Kőnig, 1908. 317.)

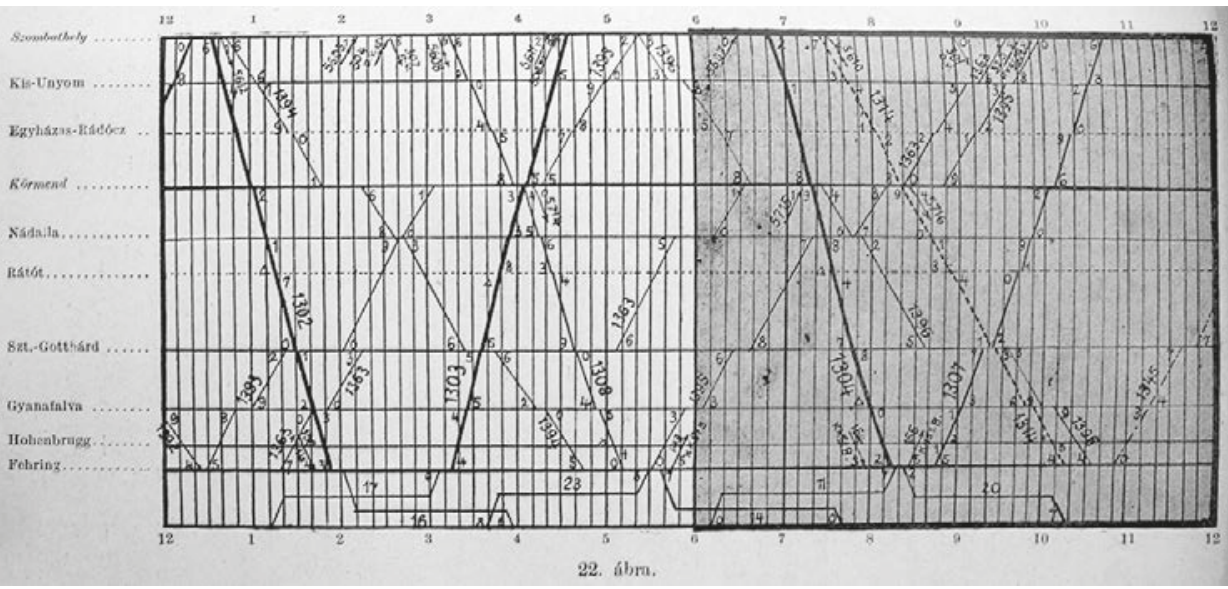

1. ábra. Menetrend-grafikon (Beke és König, 1908. 318.)

Ez a példa, több más társával együtt még nem szerepelt az említett algebra tankönyv 1897-es kiadásában.

A magyar matematikatanítási reformtörekvések között kiemelt helyen állt a differenciál- és integrálszámítás középiskolai tanításának bevezetése. Beke ennek fontosságát azzal indokolta, hogy nem is képzelhető el a természettudományos gondolkodás fejlesztése enélkül (Beke és Mikola, 1909). A differenciál- és integrálszámítás tanításának lényeges volta a fö témája az 1914-ben Párizsban, a Nemzetközi Matematikus Kongresszuson tartott főelőadásának is, mely elöadás megtartására Felix Klein kérte fel (Schubring, 1989. 190.; 2014. 191.; Zuccheri és Zudini, 2014. 503.). Rátz László és Mikola Sándor 1910-ben adták ki első tankönyvüket differenciál- és integrálszámítás témában, melynek alapját saját, gyakorlati tapasztalatokra épülő tanításuk képezte (Rátz és Mikola, 1910). A differenciál- és integrálszámítás 1914-ben lett a középiskolai tananyag része (Némethné, 2006. 35.).

Beke, Mikola, Rátz és a a többiek is, aki a reformok kidolgozása, megvalósítása terén tevékenykednek kiemelik, hogy a matematikatanítás reformja sokkal többet jelent, mint csupán a matematika tananyagának növelését. Hangsúlyozták, hogy az analízis elemeinek oktatásának a megfelelő függvényfogalmon kell, alapulnia. Már a kezdetektől fogva a tanulók gondolkodásában be kell, hogy épüljön a kapcsolatokban, függvényekben való gondolkodás.

\section{Függvények tanítása a második világháború után - az 1980-as évek végéig}

Az európai matematikatanítás alakulásában fontos szerepet játszott az 1950-es évek vége felé, meginduló modernizációs törekvés, a matematika korábbi évtizedekben végbement fejlődése alapján. A „Nicolas Bourbaki” nevével jelzett csoport tevékenysége és eredményei komoly hatással voltak a halmazelméleti-axiomatikus matematikatanítási módszer megalapozásának, amely gyakorlatilag az 1950-es évek vége felé kialakult „New Math” tanítási irányzat alapját jelentette. 
Ambrus Gabriella: Fejezetek a függvénytanítás történetéből

A 2. világháború utáni első években (1945-49), a gyors demokratizálódás haladó eszméi hatással voltak az oktatásra is. Az új középiskolás tankönyvsorozat, amely Péter Rózsa (1905-1977), Gallai Tibor (19121992) és Surányi János (1918-2006) munkájának eredményei voltak, új tartalmakat és új módszereket hoztak, melyek F. Klein reformgondolatain alapultak többségükben. Ezek a tankönyvek, noha az európai matematikadidaktikai kutatások előfutárainak tekinthetők, nem váltak külföldön ismertté, Magyarországon pedig a tanárok ellenállása miatt nem váltak sikeressé (Deák, 2002).

Az 1950-es években a középiskolás tankönyvekben (elsőként Péter Rózsa és Gallai Tibor tankönyveiben) megjelent a függvényközpontú gondolkodás a matematika más területein is, például a geometriában. A függvény fogalma ezekben a tankönyvekben is, akárcsak Beke Manó könyveiben, „mennyiségek egymástól való függését" jelentette.

Mai szemmel már bizonyára furcsának tünik, de ebben az időben még mindig léteztek az úgynevezett „,többértékü függvények is (ilyen volt például $\mathrm{y}= \pm \sqrt{x}$, pl. Borosay, 1950. 82.), szemben a mai meghatározással, mely szerint a függvény egyértelmü hozzárendelés, azaz csak „,egyértékü” lehet.

A kötelező nyolcosztályos általános iskola 1945-ben került bevezetésre - noha már korábban is szó volt róla. Az általános iskolában az 1950-es évek végéig számtan-mértant tanítottak, a tanítás elsődlegesen az elemi számolási ismeretek átadását tüzte ki célul. Az 1958-as és 1962-es tantervek bevezetésével vált fontosabbá az algebra tanítása. A „matematika” tanítása, amely az algebrán túl már elemi függvények tanítását is jelentette, a 8. osztályban jelent meg - a tankönyvek címlapján is. A 7. osztályos tananyagban az egyenes és fordított arányosság tanításával már ezek grafikus megjelenítése is szerepelt, a nyolcadik osztályos anyagban pedig „függvény” is megjelent, mint mennyiségek közötti kapcsolat- köznapi életből vett példák segítségével (például a vonat útja az utazási idő „függvénye” (vö. például Tankönyvek, 1963, 1967).

A középiskolás matematikatantervben elöször 1965-ben jelent meg a függvény definíciója következetesen, mint egyértelmü hozzárendelés értékek között és ugyanekkor vált lehetővé a függvények központi szerepének hangsúlyozása a tanításban is (Katz, 1989. 27.).
A magyar matematikatanitási

reformtörekvések között kiemelt

helyen állt a differenciál-és

integrálszámítás középiskolai

tanításának bevezetése. Beke

ennek fontosságát azzal indo-

kolta, hogy nem is képzelhetó

el a természettudományos gon-

dolkodás fejlesztése enélkül

(Beke és Mikola, 1909). A diffe-

renciál-és integrálszámítás

tanitásának lényeges volta a

fö témája az 1914-ben Párizs-

ban, a Nemzetközi Matemati-

kus Kongresszuson tartott föe-

lóadásának is, mely elóadás

megtartására Felix Klein kérte

fel (Schubring, 1989. 190.;

2014. 191.; Zuccheri és Zudini,

2014. 503.). Rátz László és

Mikola Sándor 1910-ben adták

ki elsó tankönyvüket differen-

ciál-és integrálszámítás témá-

ban, melynek alapját saját,

gyakorlati tapasztalatokra

épüló tanításuk képezte (Rátz és Mikola, 1910). A differenciálés integrálszámítás 1914-ben

lett a középiskolai tananyag

része (Némethné, 2006. 35.). 


\section{Varga Tamás és a komplex matematikatanitási kísérlet}

A függvényközpontú gondolkodás volt a Varga Tamás -féle matematika tanítási koncepció fő gondolata. Varga Tamás (1919-1987), aki többek között Pólya Gyögy tanítványa is volt, matematika-fizika szakos tanárként végzett. Már a múlt század ötvenes éveiben foglalkoztatta a matematika tanítása, megreformálása, és részt vett az Oktatási Minisztérium munkatársaként tankönyvek írásában, illetve bírálatában is.

Az 1962-ben Budapesten tartott UNESCO konferencia előadásainak hatására Magyarországon számos kisebb kutatás kezdődött, amelyek a matematikatanítás modernizációját célozták az általános iskolai, elsősorban az alsó tagozatos oktatásban. Varga Tamás is intenzívebb munkába kezdett ezen a téren. Az általa és munkatársai által képviselt alapelvek mentén indult 1964-ben a Komplex Matematikatanítási Kísérlet (Szendrei, 2007; Klein, 1987), melynek során főbb munkatársai voltak: C. Neményi Eszter, Gádor Endréné, Halmos Istvánné, Pálfy Sándor és Szendrei Julianna, de a sor korántsem teljes. Lényegében azonos feladatot vállalt magára, mint a Madison Projekt, csak jóval korlátozottabb lehetőségek között: nevezetesen, hogy a lehető legjobb matematikaoktatási lehetőséget keresi meg általános iskolás gyerekek számára (Davis, 1964, idézi Klein, S. 1987. 35.).

A kutatás a nemzetközi szinten is ismertté vált „OPI Projekt” néven (Szendrei, 2007). A legföbb kapcsolattartási lehetőséget a külföldi kutatókkal a CIEAEM (Commission Internationale pour l'Étude et Amelioration de l'Enseignement des Mathematiques) biztosította. A kapcsolattartás személyes beszélgetések révén valósulhatott csak meg, mert abban az időben a politikai körülmények miatt a magyar oktatási szakemberek nem publikálhatták eredményeiket nemzetközi szinten (Szendrei, 2007, 448.). A kísérletben sok tanár (tanár-kutató) is részt vett, akik segítették az iskolai gyakorlatba átültetni Varga Tamás gondolatait. A kísérleti évek alatt tankönyvek nélkül dolgoztak, csupán a folyamatos fejlesztés alatt álló feladatlapokat használták. Ezeknek gyűjteménye, a Munkalapok nemzetközi szinten is ismertté és elismertté váltak, például Freudenthal (1973. 244.) is elismerően szól róluk könyvében.

Varga kritikusan szemlélte a New Math tanítási irányzat koncepcióit, ő a tanulók kísérletezésen és felfedezéseken alapuló ismeretszerzését helyezte előtérbe a matematikai formalizmussal és szigorú matematikai struktúrákkal szemben. Matematikatanítási koncepciójában a függvényfogalomnak (egyértelmü hozzárendelés) központi szerepe van; a számhalmazokon értelmezett függvények egy általánosabb függvényfogalomnak csak speciális esetei, ugyanis a hozzárendelések megtalálhatók például a geometriai transzformációknál is, de gyakorlatilag az iskolai matematika bármely területén értelmezhetők. Például kombinatorikai feladatok esetében különböző eredmények változók szerinti rendezése táblázatokban szintén (táblázatokkal megadott) függvényekhez vezet (Varga, 1975. 6.).

Varga szerint a hozzárendeléseknek nem elsősorban a módja, hanem a ténye a lényeges, a tanulóknak a függvényszerü összefüggéseket fel kell tudniuk ismerni, és ez meg kell, hogy jelenjen náluk matematikán kívüli helyzetekben is (Varga, 1983). Érdemes visszautalni itt Beke Manó és munkatársai reformgondolataira, ahol a függvények, mint változó mennyiségek közötti összefüggések szintén hangsúlyos, sőt központi szerepet kaptak - de a függvény mint fogalom nem teljesen azt jelentette, mint a mai értelemben.

A függvényközpontú tananyagszemlélet és a Beke-féle reformelképzelések kapcsolatára utal a következő, Varga Tamás komplex matematikatanítással kapcsolatban készített kandidátusi értekezésében olvasható rész is, melyben Varga már a készülő és 1978-ban bevezetett új tantervre utal:

„...jogosan lehet a komplex matematikatanításon alapuló tantervet mégis függvényközpontúnak nevezni. Ez bizonyos értelemben a Felix Klein által egy évszázaddal ezelőtt kitüzött programnak a korábbinál következetesebb, a társadalom, 
a technika és a matematika mai fejlettségét is figyelembe vevő megvalósítását jelenti." (Varga, 1975. 7.)

A komplex matematikatanítási koncepció szerint a mennyiségek közötti dinamikus kapcsolatoknak már az alsó tagozaton meg kell jelennie - ahogy ezt a Beke Manó által vezetett reformok esetében is olvashattuk -, sőt, már az első osztályban. Majd éveken át érlelődve, sokféle tapasztalat birtokában kerül megfogalmazásra a függvény definíciója (mint egyértelmü hozzárendelés halmazok között), először a nyolcadik osztályban. Varga ezzel a kapcsolatokban, összefüggésekben való gondolkodás jelentőségét hangsúlyozta már kisgyerekkorban is, és ezzel együtt a megfigyelt, felfedezett összefüggések - egyszerü modellek - alkalmazási lehetőségeinek, korlátainak megfigyelését is. Egy kedves példában saját unokájával, Eszterrel kapcsolatos élményét is elmeséli, aki ötéves korában komoly felfedezést tett. Elöször lineáris kapcsolatot fedezett fel a kor és a gyerekek magassága között, majd mikor megpróbálta ezt általában kiterjeszteni az emberi életkorra és a magasságra, rádöbbent a „modell” korlátaira (Varga, 1983. 74.).

Ezzel az egyszerű példával és más hasonló, valós szituáción alapuló összefüggés segítségével jól megtapasztalható már korai gyermekkorban az is, hogy a valóságban igazán „lineárisan” ritkán függnek össze a mennyiségek, illetve el lehet beszélgetni egy esetlegesen jól közelítő lineáris modell korlátairól is.

A komplex matematikatanítási kísérlet alapján új matematika tanterv került bevezetésre fokozatosan 1974-töl kezdve, elöször az 1-4. osztályokban és önkéntes alapon. (C. Neményi, 2002).

A tanterv alapján a függvényfogalom kialakítása tehát már az első osztályban megkezdődött, és a következő években a tanulók számos gyakorlati, illetve a matematika különböző területeiről származó példa és feladat segítségével sok tapasztalatot szereztek a függvényekkel kapcsolatban. A nyolcadik osztályra megismerkedtek a halmazelméleti alapon (rendezett párokkal) történő és az egyértelmü hozzárendelés segítségével történő függvénymegadási lehetőséggel is (1. pl. a „Kockás tankönyvek” 5-8).

Az alábbi példában nemcsak hozzárendelések képi megjelenítéséhez látunk példákat, de néhány részlet látható a „Kockás tankönyvek”-re jellemző párbeszédekben megelevenedö tananyag feldolgozásra is.
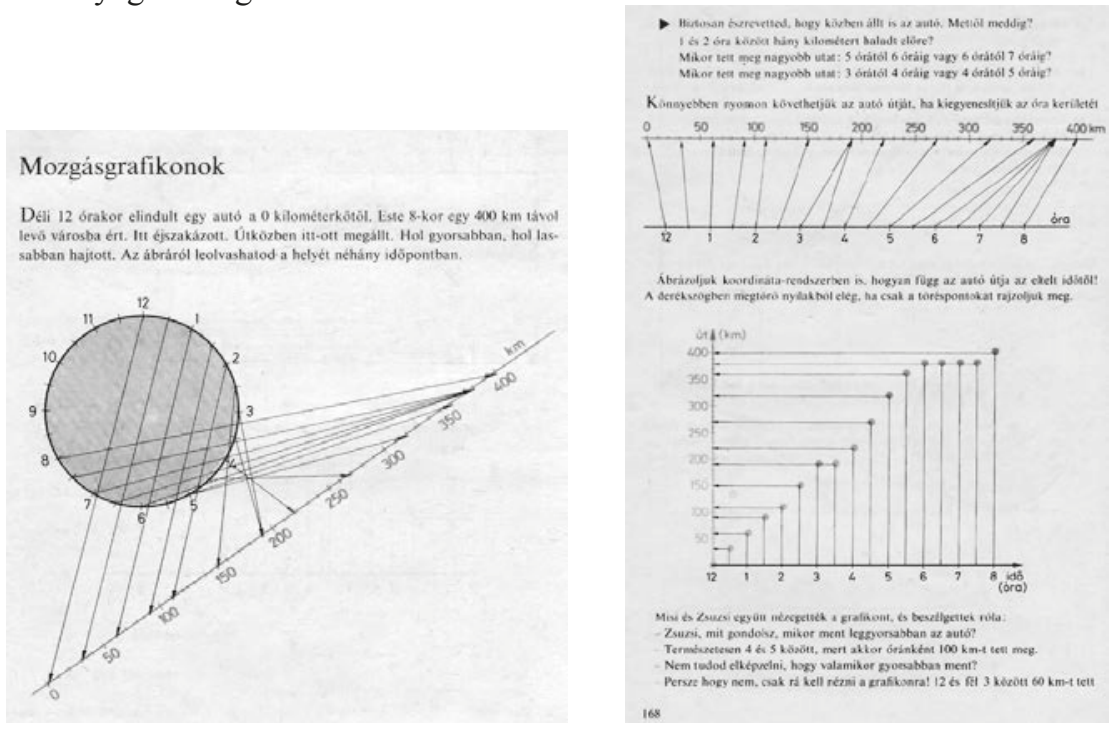

2. ábra. Példa hozzárendelések megadási lehetőségeire (Matematika 5, 167-168.) 
A függvényszerü kapcsolatok vizsgálatához, akárcsak a többi új és megújult tartalomhoz új eszközök és módszerek is tartoztak, ezeket itt nem elemezzük (vö. pl. az 1.-8. osztályos tankönyvekhez készült tanári kézikönyveket).

Az alsó tagozaton1978-ban egységesen bevezették az új matematika tantervet - Varga Tamás határozott tiltakozása ellenére, aki a fokozatos bevezetés mellett érvelt, és semmiképpen se szerette volna a tanárokra eröltetni elgondolásait (Szendrei, 2007; Klein, 1987), ez pedig gyökeres változást hozott a matematikatanítás történetében az 1-8. osztályos tananyagban. Fontos megemlíteni, hogy az 1978as tantervhez tartozó tankönyveket (1. úgynevezett „Kockás könyvek”) és munkalapokat olyan matematikatanárok és tanítók készítették, akik Varga Tamással együttmüködve a gyakorlatban is kipróbálták a módszert.

A Varga -féle koncepció és általában a függvényközpontú szemlélet megjelent az akkori középiskolás (9-12) matematikaoktatásban is, de a korábbi évfolyamokhoz képest kisebb mértékben és csak az 1970-es évek végén. Több kutatás, iskolai kísérlet is volt ebben a témában (pl. Mayerné és Pálfalvi, 1979; Katz, 1989).

Az 1979-es középiskolai matematika tanterv szerint a függvény definíciójának hivatalosan a következőt tekintették:

„Legyen az A és B két nem üres halmaz. Ha az A minden egyes eleméhez hozzárendeljük a B egy vagy több elemét, akkor az A halmazhoz hozzárendeltük a B halmazt. Az A és B halmazok közötti hozzárendelés lehet egyértelmű és nem egyértelmü. Az egyértelmü hozzárendelést függvénynek nevezzük.

A függvények tanitásában és általában a matematika tanításában a hetvenes-nyolcvanas években bekövetkezett változás mindmáig meghatározó szerepet játszik a hazai oktatásban, annak ellenére, hogy egyrészt az eredeti elgondolások egy része átalakult a következó évek tanterveiben, illetve hogy az úgynevezett "hagyományos" oktatás elemei - mely oktatási koncepció inkább a tananyag leadására, mint az átadásra és közös tudás-kialakitásra koncentrál, frontális oktatás keretében - továbbra is jelen vannak a magyar iskolákban. Ennek eredményeképpen jelenleg is akadnak például olyanok, akikben a "függvény" szó hallatán legfeljebb nevezetes függvények jól-rosszul megjegyzett "képei” (grafikonjai) jelennek meg, vagy akik számára a függvények témakör ismeretét a tananyagban szerepló elemi függvények és transzformációik elsajátítása jelzi. $\mathrm{Az}$ A halmaz a függvény értelmezési tartománya, a hozzárendelt értékek alkotják az értékkészletet, amely nem szükségképpen azonos a $\mathrm{B}$ halmazzal. A $\mathrm{B}$ halmazt képhalmaznak szokás nevezni. Jelölés: $f: A \rightarrow B, x \mapsto f(x), x \in A, f(x) \in$ " (Mayerné és Pálfalvi, 1979)

Az új középiskolás tantervhez készült új tankönyvsorozat és több pozitív változás ellenére több probléma megoldatlan maradt a függvények középiskolai tanítása terén, például gond volt, hogy az új anyag gyakorlatilag az általános iskolában korábban tanított függvénytani ismeretekre épült (Katz, 1989).

Varga Tamás módszere szerint nem volt könnyü tanítani, nemcsak új ismereteket kellett a tanároknak elsajátítani, de hagyományos módszereiket is át kellett gondolni, ami a tanártovábbképzések nagy száma ellenére a tanárok egy részének nem is sikerült, és ez 
sok feszültséget okozott. Ez bizonyára szerepet játszott abban, hogy az 1978-as tantervet az 1980-as évek második felében átdolgozták.

A függvények tanításában és általában a matematika tanításában a hetvenes-nyolcvanas években bekövetkezett változás mindmáig meghatározó szerepet játszik a hazai oktatásban, annak ellenére, hogy egyrészt az eredeti elgondolások egy része átalakult a következő évek tanterveiben, illetve hogy az úgynevezett „hagyományos” oktatás elemei - mely oktatási koncepció inkább a tananyag leadására, mint az átadásra és közös tudás-kialakításra koncentrál, frontális oktatás keretében - továbbra is jelen vannak a magyar iskolákban. Ennek eredményeképpen jelenleg is akadnak például olyanok, akikben a „függvény” szó hallatán legfeljebb nevezetes függvények jól-rosszul megjegyzett „képei” (grafikonjai) jelennek meg, vagy akik számára a függvények témakör ismeretét a tananyagban szereplö elemi függvények és transzformációik elsajátítása jelzi.

\section{Összefoglalás, kitekintés}

A huszadik század fordulóján Európa több országában megjelent az igény a matematikaoktatás, elsősorban a középiskolai matematika oktatás megreformálására és ezen belül a függvények tanításának átalakítására is (vö. Beke és Mikola, 1909, bevezetö). A matematikatanítási reformok igénye a második világháború utáni Magyarországon újult erővel jelentkezett. Az ötvenes évek új szemléletű próbálkozásai fontos alapját jelentették a későbbiekben a Varga Tamás nevével jelzett és számos matematikus, tanár és tanító szakértő és lelkes munkája nyomán megvalósult új tantervnek az 1970-es évek végén. Ebben a tantervben a függvények, a függvényszerü gondolkodás központi szerepet kapott. A vázolt tények alapján külön is érdekes a függvénytanítás történetével foglalkozni és nyomon követni egyrészt a fogalom alakulását, másrészt a függvények tanításában bekövetkezett változásokat.

Jelen tanulmány fő célja ebben a folyamatban néhány összefüggés megmutatása a múlt század eleji reformgondolatok és a jelenkori matematikatanításra döntő befolyással bíró Varga Tamás-féle koncepció között. Az utóbbi bő 100 év függvénytanításának részletes áttekintése, a vonatkozó dokumentumok elemzése még további didaktikai kutatás feladata.

A tanulmányhoz szükséges kutatások részben a Magyar Tudományos Akadémia $A$ Komplex Matematikatanitás a XXI. században - A matematikai gondolkodás fejlesztése a legújabb kutatási eredmények alapján címü Kibővített Szakmódszertani Pályázatának segítségével valósultak meg.

\section{Irodalom}

Ambrus, G. (2016). Vergangenheit und Gegenwart der ungarischen Mathematikdidaktik - unter besonderer Berücksichtigung der Bezüge zu Deutschland und Österreich, Beiträge zum Mathematikunterricht 2016, Hauptvortrag an der 50. Jahrestagung der Gesellschaft für Didaktik der Mathematik vom 07.03. bis 11.03.2016 in Heidelberg, https://eldorado.tu-dortmund.de/handle/2003/35237

Ambrus, G., Filler, A. \& Vancsó, Ö. (2016). Functional Reasoning and Working with Functions in Mathematics Teaching Tradition in Hungary and Germany. Elöadás az ICME 13 Nemzetközi Konferencián, a TSG24 munkacsoportban. Hamburg, 24-31 July 2016.
Beke M. (1896). Vezérkönyv a népiskolai számtani oktatáshoz, Budapest.

Beke M. \& Kőnig Gy. (1897). Algebra középiskolák számára. Budapest: Eggenberg féle könyvkereskedés.

Beke M. \& Kőnig, Gy. (1908). Algebra középiskolák számára. Budapest: Atheneum Irodalmi és Nyomdai Rt.

Beke M. \& Mikola S. (1909). A középiskolai matematikatanitás reformja. Budapest: Franklin Társulat Bizománya.

Borosay D. (1950). Matematika a középiskolák III. és IV. osztálya számára. Átdolgozott kiadás. Budapest: Tankönyvkiadó Nemzeti Vállalat. 
Csahóczi E., Halmos I., Radnai Gy. \& Varga K. (1981). Matematika Munkalapok. 5. Budapest: Tankönyvkiadó.

NeményiE.(2002).Azalsótagozatosmatematikatantárgy helyzete és fejlesztési feladatai. Új Pedagógiai Szemle, 12, http://epa.oszk.hu/00000/00035/00066/2002-12-hkNemenyi-Also.html

Davis, R. B. (1964). The Madison Project's approach to a theory of instruction. Journal of Research in Science Teaching, 2, 146-162. DOI: 10.1002/ tea.3660020214

Deák, E. (2002). Die besondere Verflechtung der mathematischen Forschung, des Mathematik-Unterrichts und der Mathematikdidaktik Ungarns im 19. und 20. Jahrhundert. Mitteilungen der GDM, Nr. 74.

Eglesz I., Kovács Cs. \& Sz. Földvári V. (1987). Matematika 5. Tankönyv, Budapest: Tankönyvkiadó.

Freudenthal, H. (1973). Mathematik als Pädagogische Aufgabe. Klett.

Goldzieher K. (1909). Grafikai módszerek a számtani oktatásban I. In Beke M. \& Mikola S., A középiskolai matematikatanitás reformja. Budapest: Franklin Társulat Bizománya. 73-82.

Gosztonyi, K. (2016). Mathematical Culture and Mathematics Education in Hungary in the XXst century. In Larvor, B. (szerk.), Mathematical Cultures. Basel: Springer Birkhäuser. DOI: 10.1007/978-3-31928582-5 5

Kántor T. (2014). Arcképek a 20. század magyar matematikusairól: Beke Manó. Polygon, 22(1-2), 3-20.

Katz S. (1989). Függvények korszerü felfogásban. Budapest: Tankönyvkiadó.

Kelemen J. \& Mosonyi K. (1967). Matematika 8. Budapest: Tankönyvkiadó.

Klein, F. (1932). Elementary Mathematics from an Advanced Standpoint: Arithmetic, Algebra, Analysis. New York: The Macmillan Company (Original published in 1908).

Klein, S. (1980). A Komplex Matematikatanitási Módszer pszichológiai hatásvizsgálata. Budapest: Akadémiai Kiadó.

Mayerné Bartal A. \& Pálfalvi J. (1979). Matematika munkatankönyv. I. Budapest: Tankönyvkiadó. (Készült az Oktatási Minisztérium rendeletére az Országos Pedagógiai Intézet közremüködésével. Bírálók: Deák Ervin, Pálmay Lóránt, Vidéki Gusztávné. Az OPI részéről véleményezte Urbán János).

Némethné Pap K. (2006). Rátz László tanár úr. Studia Physica Savariensia, XIII, Szombathely. http:// docplayer.hu/203594-Ratz-laszlo-tanar-ur.html
Rátz L. \& Mikola S. (1910). Az infinitezimális számítások elemi a középiskolában. Budapest: Franklin Társulat.

Schubring, G. (2014). Mathematics Education in Germany (Modern Times) Chapter 12. In Karp, A. \& Schubring, G. (szerk.), Handbook on the History of Mathematics Education. New York: Springer. 241255. DOI: 10.1007/978-1-4614-9155-2_12

Schubring, G. (1989). Pure and Applied Mathematics in Divergent Institutional Settings in Germany: The Role and Impact of Felix Klein, 171-222. In Rowe, D. E. \& McCleary, J. (szerk.), History of Modern Mathematics, Vol. II, Institutions and Applications. Academic Press, 190. https://books.google. hu/books?id=emriBQAAQBAJ\&pg=PA190\&lpg=PA190\&dq $=$ Emanuel + Beke $\&$ source $=$ bl\&ots $=\mathrm{KC}$ eS4c-EO\&sig=AwDHywn9MUERBXa4vk68xFIFmTI\&hl=hu\&sa=X\&ei=L5bHVNKOEsWBU6jwg $\mathrm{gD} \& \mathrm{ved}=0 \mathrm{CC} 8 \mathrm{Q} 6 \mathrm{AEwBjgK} \# \mathrm{v}=$ onepage $\& \mathrm{q}=\mathrm{Em}-$ anuel\%20Beke\&f=false DOI: $10.1016 /$ b978-0-08092546-2.50013-5

Schubring, G. \& Kántor, T. (é. n.). Emanuel Beke. http://www.icmihistory.unito.it/portrait/beke.php\#up

Stéger \& Bellay. (1963). Számtan és Mértan az általános iskolák VII. osztálya számára. Budapest: Tankönyvkiadó.

Szendrei, J. (1996, szerk.). Mathematics in Hungary. Budapest: Bolyai János Matematikai Társulat.

Szendrei, J. (2007). In memory of Tamás Varga. http://www.cieaem.org/?q=system/files/varga.pdf

Szendrei, J. (2007). When the going gets tough, the tough gets going, problem solving in Hungary, 1970 2007: research and theory, practice and politics. Zentralblatt für Didaktik der Mathematik, 39, 443-458. DOI: 10.1007/s11858-007-0037-0

Tanterv az általános iskola számára (1956) Budapest: Tankönyvkiadó.

Tanterv az általános iskola számára (1962) Budapest: Tankönyvkiadó.

Varga Tamás (1969). A matematika Tanitása. Egyetemi jegyzet. Budapest: Tankönyvkiadó.

Varga Tamás (1975). Komplex Matematika, kandidátusi alkotás ismertetése. Kézirat. Magyar Tudományos Akadémia.

Varga, T. (1988). Mathematics Education in Hungary today. Educational Studies in Mathematics, 19 , 291-298. DOI: 10.1007/bf00312449

Varga Tamás (1983). A függvényfogalom elökészítése I. A Matematika Tanitása, 3, 66-75.

Zuccherini, L. \& Zudini, V. (2014). History of Teaching Calculus. In. Karp, A. \& Schubring, G. (szerk.), Handbook on the History of Mathematics Education. New York: Springer. 493-515. DOI: 10.1007/978-14614-9155-2_24 